\title{
Barriers to Using LMS-Edmodo on Speaking Tasks: Students' Perception
}

\author{
Rifki Irawan ${ }^{1, *}$, Nafisah Endahati ${ }^{1}$, Rian Nurizka $^{2}$, Rianto $^{3}$, Drajat Edi Kurniawan ${ }^{4}$ \\ ${ }^{1}$ Department of English Language Education, Faculty of Teacher Training and Education, University of PGRI Yogyakarta, Indonesia \\ ${ }^{2}$ Department of Indonesian Language and Literature Education, Faculty of Teacher Training and Education, University of PGRI \\ Yogyakarta, Indonesia \\ ${ }^{3}$ Department of Informatics, Faculty of Science and Technology, University of PGRI Yogyakarta, Indonesia \\ ${ }^{4}$ Department of Guidance and Counseling, Faculty of Teacher Training and Education, University of PGRI Yogyakarta, Indonesia
}

Received July 13, 2020; Revised September 4, 2020; Accepted September 17, 2020

\section{Cite This Paper in the following Citation Styles}

(a): [1] Rifki Irawan, Nafisah Endahati, Rian Nurizka, Rianto, Drajat Edi Kurniawan, "Barriers to Using LMS-Edmodo on Speaking Tasks: Students' Perception," Universal Journal of Educational Research, Vol. 8, No. 11, pp. 5305 - 5311, 2020. DOI: 10.13189/ujer.2020.081131.

(b): Rifki Irawan, Nafisah Endahati, Rian Nurizka, Rianto, Drajat Edi Kurniawan (2020). Barriers to Using LMS-Edmodo on Speaking Tasks: Students' Perception. Universal Journal of Educational Research, 8(11), 5305 - 5311. DOI: 10.13189/ujer.2020.081131.

Copyright $\odot 2020$ by authors, all rights reserved. Authors agree that this article remains permanently open access under the terms of the Creative Commons Attribution License 4.0 International License

\begin{abstract}
Using Learning Management System (LMS) is ubiquitous in higher education now, but sometimes teachers do not understand its barriers before implementing it. This research aims to explore the obstacles to using LMS-Edmodo on EFL speaking tasks based on the students' perceptions. It involved ten business college students from a private university in Yogyakarta, Indonesia, and employed a qualitative descriptive approach that applied several instruments such as observation, documentation, and interview. The data were collected by a screen capture tool to find the students' tasks on Edmodo that contained barriers indications and collaborated with an interview before they were transcribed and coded by using three stages of qualitative analysis, which were data reduction, data display, and conclusion drawing and verification. Based on the students' perceptions, the barriers to using Edmodo on EFL speaking tasks are requiring high speed of Internet connection, needing other supports for technologically backward students, lack of virtual teachers support and needing $\mathrm{f} 2 \mathrm{f}$ meeting. Therefore, providing speaking tasks as long as paying attention to the students' characteristics can use LMS-Edmodo.
\end{abstract}

Keywords Barriers, Edmodo, Learning Management System, Speaking Tasks

\section{Introduction}

In industrial Revolution 4.0, students encounter a world transformed by technology that creates new barriers and strain for formal education systems [1]. Computer, Internet, and social media are examples of technology development [2-4]. world-wide-web leads the use of Internet technology to support a teacher and students in applying the blended-learning method, which is the combination of technology utilisation with face-to-face (f2f) instruction [5]. Also, the existence of LMS technologies can facilitate and motivate EFL teaching and learning processes [1].

LMS can be used by teachers to distribute courses and interact with students from afar [6]. It also can be used to manage tracking learning activities and results such as quizzes, assignments, and grading [7]. Besides, assessment tools and student progress reports are also provided in this technology [8]. LMS is designed to achieve the following objectives, which are enabling learning practises of all participants online and offline in the active environment, improving the involvement of students in the dynamic educational process, creating conditions for intense student-teacher interaction and improving teacher's, and students' digital skills [1].

In higher education, the use of the learning management system (LMS) in online or distance learning courses is widespread [9]. In more top education fields, the 
incorporation of an LMS into studying and teaching activities expanded [10]. Motivation factors and integration of instructional technology research indicate a correlation between instructional activities and motivation [11]. Open-source LMS platforms are becoming a choice for each institution, as they benefit users by allowing platforms to be modified according to user requirements and due to the low cost of obtaining a better service compared to a commercial platform [8]. However, the use of open-source LMS platform is not accompanied by the skill, even the knowledge to operate them. The teachers sometimes do not have considered choosing the most effective LMS platform implemented in the class. Moreover, they only apply the platform that is familiar for them without deliberating what subjects, skills to be taught and what cultures, characteristics, and abilities students have. As a result, teachers have problems in the process of conducting distance learning that also effects on achieving learning objectives that have been decided before.

There are numerous studies related LMS in teaching and learning; for examples, its considerations [12-14], implementation [15-17], and evaluations [18-20] Those previous researches are quite similar to this research, which discuss the implementation of an LMS platform in teaching and learning. However, the barriers to using LMS on speaking tasks have not been studied yet, as we know. Hence, before choosing the most appropriate LMS platform, the teacher should know its obstacles first. Therefore, this research seeks to answer the question; what are the barriers to using LMS-Edmodo on speaking tasks based on students' perceptions?

\section{Literature Review}

\subsection{Learning Management System (LMS)}

There are so many open-source platforms providing LMS that can be used by the teacher and students. Three of them are Schoology, MODDLE, and Edmodo; on the other hand, Edmodo gains prominence across this audience as 'The Best Applications for teachers have over 50 million members worldwide [21]. Edmodo is a closed social learning network that is considered unique in comparison with other social networking sites (SNSs) like Facebook and Twitter because it gives users a safe and private setting [22]. In other words, each student has a unique access code, which no strangers can become a member except him/her; parents also have their code, allowing them to check and work with young learners while at the same time, ensuring that the interaction between the learners among their peers is safe. Therefore, Edmodo is an open-source LMS platform that supports secure LMS facilities.

\subsection{Edmodo}

Edmodo, which can be accessed on www.edmodo.com and the play store or app store for smartphone apps, is designed to provide features that are very easy to use and navigate. It doesn't take time to load the pages when you go to the website, because it has low graphics. A teacher can create a virtual learning class in minutes in this e-learning, and invite the students to participate. Meanwhile, by clicking "join a class" the students can build new user accounts, then typing a teacher's "group code." Students write their user names, email and passwords to become a part of the virtual class after that. After successfully signing in, the students are given many features of online learning. These features are straightforward to interact and connect with the Edmodo users, both an instructor and students. Edmodo provides many features that support users to boost their learning [23].

\subsubsection{Groups}

Teachers should create a group to bring their students into the virtual meeting from the conventional $\mathrm{f} 2 \mathrm{f}$ meeting. They get a group code after forming a group that should be shared with the students. This group code keeps the online learning class safe and private; as none can participate except the group members. Also, teachers can interact with others around the world in the co-teaching model, thereby providing a discussion platform where their students can connect with others. On the other hand, teachers may also divide the students into smaller subgroups when learning tasks need to differ.

\subsubsection{Posts}

Teachers and students may post all such messages, links, or files to the entire community or subgroup. Teachers can also post directly to individual students and their parents.

\subsubsection{Alerts}

If they need to exchange important messages or updates, teachers may use alerts, which will appear in greater and thicker font than regular updates. The students also accept the notifications, but only teachers can use this feature.

\subsubsection{Quizzes}

The teachers can choose freely the quizzes formats. They can be a multiple-choice, true/false, short answer, or blank fill-in format. The function has pacing, immediate scoring and weighted questions to make it more difficult.

\subsubsection{Libraries and Folders}

Teachers can upload files and links to the Edmodo libraries in this section and can manage them in folders to be shared with unique classes. Furthermore, students may use libraries and directories to share or discuss with their classmates.

\subsubsection{Calendar}

The calendar will remind the students of the teachers' tasks, so they can remember when they should apply for 
their work. So they can control their time in this immersive learning effectively.

\subsubsection{Grade book}

The teachers will rate them in the grade book after reviewing the works of the students in assignments and quizzes, and the final grades can be translated into Microsoft Excel.

\subsubsection{Badges}

Teachers may use awards to honour the students for their accomplishments. Via Edmodo, a teacher may make their badges, or take ideas from others.

\subsection{Speaking Tasks}

Speaking is one of the macro competencies in teaching and learning English. Speaking, like writing, forms part of a productive skill. There are so many definitions of speaking that some language learning experts have stated. Speaking is the productive oral skill, consisting of systematic verbal utterance to convey meaning [24]. It can be observed either directly or empirically where the observations are influenced by the accuracy and efficacy of the students' listening skills, which compromise the reliability and validity of an oral production test [25]. The teacher can use several tasks, including communication games, discussions, prepared talk, and role-plays, to improve the speaking skills of the students [26].

Communication games in the students develop the correct habits of speech. The teacher divides the students into two different groups. He gives them the question to frame and to ask them to converse [27]. Moreover, there are two categories of communication games, which are information gap games and television and radio games [26]. Information gaps can be reached when one student talks to a partner by ordering to solve a puzzle, drawing a picture, and putting things in the right order to find similarities and differences between images.

Furthermore, Fishbowl, which belongs to the television and radio games, can provide enjoyable fluency activities. Two students speak on any topic they like, but at a pre-arranged signal, one of them has to reach into a fishbowl and take out one of many pieces of paper on which students have previously written phrases, questions, and sentences. Students have to incorporate whatever is on the paper into the conversation straight away. Therefore, communication games, especially digital learning playground, has successfully helped in encouraging students to speak by playing and learning with adequate context-relevant immersions and efficient game instruction management [28].

Discussion can be categorized as discussion cards, warm-up discussion, balloon debate, pyramid debate, and panel discussion [29]. The use of debate significantly improves the critical thinking and speaking skills of the students [30]. Besides, the fishbowl debate assisted students in using English for authentic and meaningful purposes while at the same time appreciating its relevance to the examination [31]. If debates are adequately practised, students will have confidence in academic, social, and professional users of the English language, so that it can improve their English as well as their presentation skills [32].

In the prepared talk, students may have some time to write guidelines or notes of their prepared topic and practise giving a speech before [26]. The advantages of presentation are integrating language skills, practising speaking, making decisions, preparing for real life, acquiring knowledge through English promoting learning-centeredness, expanding the teacher's role, and learning how to use technology [33]. The combination among presentation with encounter project and the poster session encourage language learners to communicate their classmates with research, knowledge gains and opinions [34].

The incorporation of role-plays in the language classrooms is a handy language teaching tool as it stimulates the use of target language in real situations, involves learners in creative learning, and is fun and motivating for learners [35]. Role-play activities require several steps [36]. Firstly, language instructors must first select a suitable situation/context for a role play, bear in mind the needs and interests of the learners, and allow them to practise what they have learned. Secondly, after selecting the context (setting the scene), it involves designing the role play, which should take into consideration the level of language skills of the learners. The last, instructors are required to generate two or more roles for learners in the role-play.

The teacher needs to take into consideration several factors in choosing or creating an activity or task to promote speaking [37]. First, the activity, or task, should contribute to the course's required results. Second, it should be an activity or task that can be accomplished by the students in the class. Factors affecting task difficulty include not only the level of linguistic complexity but also the comprehensibility of the task, its cognitive problem, the scaffolding (or its absence) provided within the task, and its ability to interest and motivate the learners.

\subsection{Students' Perception}

Perception uses mechanisms of the senses and cognition to understand the world around us. It is a unique way of interpreting phenomena through the perception of sensory knowledge based on experience, information processing, and mental models [38]. Moreover, it is a collection of the brain's internal sensational cognitive processes at the subconscious cognitive function layer that detects, relates, perceives, and searches within the mind for internal cognitive knowledge [39]. Students' perception is a method of using the information that has been learned to obtain and perceive stimuli that are recognized in the 
human senses by the system [40].

\section{Materials and Methods}

The research was conducted at the University of PGRI Yogyakarta, which was located at sonosewu street no. 117, Yogyakarta, Indonesia. This place was chosen because the researcher conducted a teaching-learning process there. It was done in January - July 2020. The data was obtained based on the researcher's teaching schedule, which was held once a week, and it took 2 hours in each meeting.

Purposive sampling was employed in selecting the participants. The researcher intentionally selected the participants who could provide the best information to achieve the objective of the study. The research participants of this study were ten students of the University of PGRI Yogyakarta.

This research used a qualitative descriptive approach. The phenomenon and valuable information will be deeply explored that will offer a way to see the issue from the subject view [41]. It investigated the students' perceptions of a phenomenon [42]. Therefore, this research explored deeply about barriers to using LMS-Edmodo based on students' perception of the speaking tasks.

In collecting data, the researcher used three instruments. The instruments in this research were observation, documentation, and interview. Observation is the procedure of collecting optional, tangible information by monitoring individuals, and research sites [41]. The researcher did the observation to monitor the implementation of LMS-Edmodo in English speaking tasks, particularly its barriers. Hence, all students' activities like comments, messages, both in the $\mathrm{f} 2 \mathrm{f}$ and online learning that were related to Edmodo's restrictions, were observed. When the researcher found the activities containing barriers indication, a screen capture was used to record the data.

This research used semi-structured interviews to understand the experiences of the subjects because the goal of this research explored the barriers to using LMS-Edmodo as e-learning on speaking tasks and tried to find the freer responses from participants of some basic ideas that need to cover. The interview was in Indonesia to prevent misunderstanding and managed to pursue the students' perceptions toward barriers to using LMS-Edmodo on speaking tasks. The transcripts of conversation were recorded and transcribed to avoid inaccuracy and incompleteness data. Then the data gathered were analyzed using the three stages of qualitative analysis [43], data reduction, data display, and conclusion drawing and verification.

\section{Results \& Discussion}

Based on the students' perception, there are several barriers to using LMS-Edmodo on speaking tasks.

\subsection{Requiring High Speed Internet Connection}

An Internet connection is another barrier when implementing Edmodo as an LMS platform in Indonesia, especially if using it for speaking activities. Whether the students wanted it or not, they should depend on the slow Internet connections to join every speaking task in this platform. For example, because of slow Internet connections, it needed time when uploading a video project that had a big size. As a result, it brought negative impacts to the students, such as frustration and unmotivated, to do the assignments. Frustration and harmful impact on learning could occur when poor Internet connectivity used by the students in using the LMS platform [48].

\section{Excerpt 4}

"Uploading the video on Edmodo makes me frustrated."

\subsection{Needing Other Supports for Technologically Backward Students}

In this Industrial Revolution 4.0 right now, not all students understand how to use technology in learning. Technologically backward students may be unable to participate the digital learning if they lack another support [46,47]. Implementing Edmodo in the classroom requires skills of computer and sometimes files and software management of it, which could be complicated for those students.

Based on the observation, several students got problems when using an LMS-Edmodo on speaking tasks. They did not understand how to do and send assignments; even though the teacher had explained and given them a guide book to use it. Moreover, in the middle of meeting total, some students forgot their Edmodo user names and passwords. This case often happens when their smartphone was broken. As a result, they had to create the new one to keep joining the speaking tasks over there.

\section{Excerpt 1}

"I forgot my user name and password, and the teacher gave me the group code to create the new one."

\subsection{Lack of Virtual Teachers Support}

The lack of teacher's support is another barrier. When the students needed the teacher's help, they could contact him via WhatsApp or Edmodo Private Message. However, it took time until the teacher answered their query; even he did not respond to it at all. This condition made them confused, but it could be solved when they discussed the problems with other peers.

\section{Excerpt 2}

"I texted the teacher at 07.00, but until the night he has not yet replied."

\subsection{Requiring F2F Meeting}

All problems encountered by the students during joining 
activities on Edmodo made them more confused about the material given. The existence of confirmation from the teachers in f2f meeting was something expected.

\section{Excerpt 5}

"When I do not understand the activities on Edmodo, I texted the teacher either via WhatsApp or Edmodo Private Messages. Sometimes he responded it, even not at all. I need face-to-face-meeting"

Social interactions on Edmodo are mainly virtual and different from face-to-face classroom interaction [49]. As a result, there are some challenges caused by the use of this kind of learning. First, the students argued that the explanation in the conventional education was more understandable than on Edmodo classroom. In that learning, students could directly communicate their views and elucidate their inquiries with the teacher. Consequently, they got their questions answered clearly.

\section{Excerpt 6}

"In the classroom (face to face meeting), I can clearly understand the teacher's explanation than in the online classroom (Edmodo)."

Several students often did not understand its speaking instructions posted on Edmodo; They confessed that besides the direction written in English, it also contained a short explanation, which made them, should clarify by asking the teacher via other social media. Due to the lack of clarifications, description, and interpretation, Edmodo can be less effective than the traditional one [50].

\section{Excerpt 7}

"I do not understand well the teacher's instruction (on Edmodo), and I should ask him for clarification."

Third, some students did not understand completely the virtual feedback provided on Edmodo. They assumed that an actual teacher's one-to-one, face-to-face feedback was more valuable. Because of this, in the face-to-face meeting, they needed to clarify and to enquire feedbacks that made them known their mistake and error so that they did a similar assignment correctly in the future. The lack of an actual teacher's one-to-one, face-to-face feedback resulted in difficulties in the students' understanding [49].

\section{Excerpt 8}

"I have not understood the teacher's note yet in my assignment (feedback) until I clarify them in the face to face meeting."

\section{Conclusions}

There are some obstacles to using LMS-Edmodo while speaking, such as requiring high-speed internet access, needing some support for technologically backward students, lack of virtual teacher support and having f2 $\mathrm{f}$ meetings to explain teacher guidance and feedback.

Furthermore, this present study is beneficial to some following parties. This research gives benefits to the
English teacher in enhancing the knowledge on the potential and challenges of using Edmodo as e-learning in the speaking activities. In the industrial revolution 4.0 now, the use of technology, especially the Internet, is needed, and the teacher should have those skills to keep up with the times. If it compares with traditional learning, online learning has more benefits. Furthermore, if it also combines with the informative face to face meeting, the students' autonomous learning will increase.

For the students in Indonesia, although the Internet connection in this country is not as fast as the others, the use of Edmodo in speaking activities can facilitate the students to practise speaking and to develop their vocabularies outside the real classroom. Therefore, by increasing the time of learning and practising, the students' speaking skills will increase.

This research has given evidence that there were some barriers to implementing an LMS-Edmodo on speaking tasks. Furthermore, innovative blended learning can be achieved successfully by using this platform. On the other hand, the investigations of using Edmodo in other skills such as reading, listening, and writing are expected to be conducted in the future research in order to give more pictures about the use of an LMS in learning English.

\section{Acknowledgements}

We are very grateful to LPPM UPY and the rector of UPY for their appropriate and constructive suggestions to improve this research.

\section{REFERENCES}

[1] Lyashenko MS, Malinina IA. The Use of Learning Management System Projects for Teaching a Foreign Language in the University. Procedia - Soc Behav Sci [Internet]. 2015;182:81-8. Available from: http://dx.doi.org/10.1016/j.sbspro.2015.04.741

[2] Egbert J. CALL (Computer-Assisted Language Learning) Methodology. TESOL Encycl English Lang Teach. 2018;(2014):1-6.

[3] Kassab M, DeFranco J, Laplante P. A systematic literature review on Internet of things in education: Benefits and challenges. J Comput Assist Learn. 2020;36(2):115-27.

[4] Rahman S, Ramakrishnan T, Ngamassi L. Impact of social media use on student satisfaction in Higher Education. High Educ Q. 2019;(January):1-16.

[5] Garrison DR, Vaughan ND. Blended Learning in Higher Education; Framework, Principles, and Guidelines. San Fransisco: Jossey-Bass; 2008.

[6] Almarashdeh IA, Sahari N, Zin NAM, Alsmadi M. The success of learning management system among distance learners in Malaysian universities. J Theor Appl Inf Technol. 
2010;21(2):80-91.

[7] Srichanyachon N. EFL learners' perceptions of using LMS. Turkish Online J Educ Technol. 2014;13(4):30-5.

[8] Kasim NNM, Khalid F. Choosing the right learning management system (LMS) for the higher education institution context: A systematic review. Int $\mathrm{J}$ Emerg Technol Learn. 2016;11(6):55-61.

[9] Navimipour N, Zareie B. A model for assessing the impact of e-learning systems on employees' satisfaction. Comput Human Behav [Internet]. 2015;53:475-85. Available from: http://dx.doi.org/10.1016/j.chb.2015.07.026

[10] Ashrafzadeh A, Sayadian S. University instructors' concerns and perceptions of technology integration. Comput Human Behav [Internet]. 2015;49:62-73. Available from: http://dx.doi.org/10.1016/j.chb.2015.01.071

[11] Gautreau C. Motivational factors affecting the integration of a learning management system by faculty. J Educ Online. 2011;8(1):1-25.

[12] Golshan N, Tafazoli D. Technology-enhanced Language Learning Tools in Iranian EFL Context: Frequencies, Attitudes and Challenges. Procedia - Soc Behav Sci [Internet]. 2014;136:114-8. Available from: http://dx.doi.org/10.1016/j.sbspro.2014.05.299

[13] Snoussi T. Learning Management System in Education: Opportunities and Challenges. Int J Innov Technol Explor Eng. 2019;8(12S):664-7.

[14] Govindasamy T. Successful implementation of e-Learning Pedagogical considerations. Internet High Educ. 2001;4(34):287-99.

[15] Chanpet P, Chomsuwan K, Murphy E. Online Project-Based Learning and Formative Assessment. Technol Knowl Learn [Internet]. 2020;25(3):685-705. Available from: https://doi.org/10.1007/s10758-018-9363-2

[16] Aldiab A, Chowdhury H, Kootsookos A, Alam F, Allhibi H. Utilisation of Learning Management Systems (LMSs) in higher education system: A case review for Saudi Arabia. Energy Procedia [Internet]. 2019;160(2018):731-7. Available from: http://dx.doi.org/10.1016/j.egypro.2019.02. 186

[17] Sanprasert N. The application of a course management system to enhance autonomy in learning English as a foreign language. System [Internet]. 2010;38(1):109-23. Available from: http://dx.doi.org/10.1016/j.system.2009.12.010

[18] Abdullateef BN, Elias NF, Mohamed H, Zaidan AA, Zaidan BB. An evaluation and selection problems of OSS-LMS packages. Springerplus. 2016;5(1):1-35.

[19] Kraleva R, Sabani M, Kralev V. An analysis of some learning management systems. Int $\mathrm{J}$ Adv Sci Eng Inf Technol. 2019;9(4):1190-8.

[20] Hidayat ML, Prasetiyo WH, Wantoro J. Pre-service student teachers' perception of using google classroom in a blended course. Humanit Soc Sci Rev. 2019;7(2):363-8.

[21] Sfenrianto S, Tantrisna E, Akbar H, Mochamad W. E-learning effectiveness analysis in developing countries: East nusa tenggara, Indonesia perspective. Bull Electr Eng Informatics. 2018;7(3):417-24.
[22] Khodary MM. Edmodo Use to Develop Saudi EFL Students' Self-Directed Learning. English Lang Teach. 2017;10(2):123.

[23] Holzweiss K. Edmodo: A Great Tool for School Librarian. Sch Libr J. 2013;

[24] Nunan D. Practical English Language Teaching. New York: McGraw-Hill; 2003.

[25] Brown DH. Teaching by Principles. 2004. p. 246.

[26] Harmer J. The Practice of English Language Teaching. 4th editio. Harlow: Pearson Education Limited; 2007. 448 p.

[27] Patel MFPMJ, Praveen. ENGLISH LANGUAGE TEACHING (METHODS, TOOLS \& TECHNIQUES) [Internet]. Jaipur: SUNRISE PUBLISHERS \& DISTRIBUTORS; 2008. Available from: http://www.oxfor dscholarship.com/view/10.1093/acprof:oso/9780199574797 .001.0001/acprof-9780199574797-chapter-18

[28] Wu CJ, Chen GD, Huang CW. Using digital board games for genuine communication in EFL classrooms. Educ Technol Res Dev. 2014;62(2):209-26.

[29] Thornbury S. How To Teach Speaking.pdf. 2002.

[30] Iman JN. Debate instruction in EFL classroom: Impacts on the critical thinking and speaking skill. Int $J$ Instr. 2017;10(4):87-108.

[31] Yung KWH. Using Public Exam Questions in Fishbowl Debate to Engage Exam-Oriented Students in Communicative Language Teaching. RELC J. 2020;

[32] Alasmari A, Ahmed SS. Using debate in EFL classes. English Lang Teach. 2013;6(1):147-52.

[33] Al-Issa AS, Al-Qubtan R. Taking the Floor: Oral Presentations in EFL Classrooms. TESOL J. 2010;1(2):22746.

[34] McCafferty E, Ford K. Making student presentations interactive in the context of Japanese EFL classrooms. TESOL J [Internet]. 2000;30-1. Available from: http://onlinelibrary.wiley.com/doi/10.1002/j.1949-3533.200 0.tb00266.x/abstract

[35] Benati A. Role Play. In: The TESOL Encyclopedia of English Language Teaching [Internet]. Hoboken, NJ, USA: John Wiley \& Sons, Inc.; 2018. p. 1-4. Available from: http://doi.wiley.com/10.1002/9781118784235.eelt0182

[36] Savignon SJ. Communicative Competence: Theory and Classroom Practice. Mod Lang J. 1998;82(4):594.

[37] Low G. Interactive Activities for Promoting Speaking. TESOL Encycl English Lang Teach. 2018;1-8.

[38] Mcdonald SM. Perception: A concept analysis. Int J Nurs Knowl. 2012;23(1):2-9.

[39] Wang Y. On the Cognitive Processes of Human Perception with Emotions, Motivations, and Attitudes. Int J Cogn Informatics Nat Intell. 2007;1(4):1-13.

[40] Pebriantika L, Paristiowati M, Mochtar H. Students' perceptions of mobile technology in higher education: Preparation to design mobile learning models. Univers $\mathrm{J}$ Educ Res. 2019;7(9 A):180-5. 
[41] Creswell J. Educational research: planning, conducting and evaluating quantitative and qualitative research [Internet]. fourth edi. Boston: Pearson Education; 2012. Available from: http://www.ghbook.ir/index.php?name=eى نuو\&option=com_dbook\&task=readonline\&book_id=136 50\&page $=73 \&$ chkhashk=ED9C9491B4\&Itemid=218\&lang $=$ fa\&tmpl=component

[42] Maxwell J. Qualitative Study. In: Social Sciences. 2006. p. $1-7$.

[43] Miles M, Huberman AM. Qualitative Data Analysis. Newbury: CA SAGE; 1994.

[44] Stalin P, Abraham SB, Kanimozhy K, Prasad RV, Singh Z, Purty AJ. Mobile phone usage and its health effects among adults in a semi-urban area of Southern India. J Clin Diagnostic Res. 2016;10(1):LC14-6.

[45] Jalal A, Zaidieh Y. The Use of Social Networking in Education: Challenges and Opportunities. World Comput
Sci Inf Technol J. 2012;2(1):2221-741.

[46] Nielson KB. Self-study with language learning software in the workplace: What happens? Lang Learn Technol. 2011;15(3):110-29.

[47] Barnawi OZ. The Internet and EFL College Instruction: A Small-Scale Study of EFL College Teachers' Reactions. Int J Instr Technol Distance Learn. 2009;6(6).

[48] Akpan ET. Blended Learning Opportunities and Challenges in Mathematics Education: Perspective in Higher Education. South Am J Acad Res. 2015;2(1).

[49] Soliman NA. Using E-Learning to Develop EFL Students' Language Skills and Activate Their Independent Learning. Creat Educ. 2014;05(10):752-7.

[50] Abaidoo V, Arkorful N. The role of e-learning, advantages and disadvantages of its adoption in higher education. Int $\mathbf{J}$ Instr Technol Distance Learn. 2015;2(12):7. 